\title{
EFFECTIVENESS OF HUMAN RESOURCE MANAGEMENT PRACTICES, ON THE SALES GROWTH OF THE ORGANIZATION
}

\author{
S. PRATIBHA ${ }^{1} \&$ J. KATYAYANI ${ }^{2}$ \\ ${ }^{I}$ Research Scholar, Department. of Business Management, SPMVV, Tirupathi, India \\ ${ }^{2}$ Research Supervisor, Department. of Business Management, SPMVV, Tirupathi, India
}

\begin{abstract}
Human resource management practices have been considered as an important and critical area in the management and organization performance. Many organizations described human resource as the combination of traditionally administrative personnel functions with performance management, employee relations and resource planning. HR planning is strategic and very important part in the process of organizational system in order to achieve success. The study on the effectiveness of HRM practices contributes significantly to the performance ofthe organization irrespective of whether they are large scale or small scale industries. Human resource management is the framework of the HRM practices consists of any intentional introduction or change of HRM program, policy, practice or system designed to influence employee the skills, behavior and interactions of employees and have the potential to provide both the foundation for strategy formulation and the means of strategy implementation that is perceived to be new and create current capabilities and competencies. Som (2006). Human resource managers and business owner need to play an important role in to overcome the problems of employee absenteeism/turnover intentions especially in small and medium enterprises. This paper focuses on identifying the effectiveness of HRM practices on the performance of small scale industries. This paper studies the effectiveness of HR practices like Recruitment, Training and Development, Compensation and Performance appraisal on the performance of small scale industries.
\end{abstract}

KEYWORDS: HR Practices, Policies, Strategy Formulation, Organization Performance \& Small Scale Industries

Received: Oct 20, 2017; Accepted: Nov 11, 2017; Published: Dec 01, 2017; Paper Id.: IJBMRDEC20174

\section{INTRODUCTION}

Human resource plays a very important role in the growth of any organization. Human resource management is a strategic and very important part in the process of management of effective organization system. Many organizations describe Human resource as the combination of traditional and administrative personnel functions with performance management, employee relations and resource planning. The main objective of HR is to maximize return on investment from organization's human capital. In order to maximize organizational effectiveness, human potential, individual's capabilities, time and talents must be used efficiently. Human resource management ensures that employees are capable to meet the organizations goals. HRM is responsible for bringing people into the organization, help them to perform their work, pays compensation for their labor and solves the problems faced by them in their work environment. Organizations awareness towards the important of human resources is increasing day by day in today's changing business environment. Human resource planning, if used properly, leads to the maximum utilization of human resources, reduces labor turnover, high absenteeism, improves productivity and helps in achieving objectives of the organization. Human resource management refers 
to a set of programs, functions and activities designed and carried out in order to maximize both employee as well as organizational effectiveness.

\section{DEFINITIONS OF HUMAN RESOURCE MANAGEMENT}

- Edwin B. Flippo - Human resource management is "The planning, organizing, directing and controlling of the procurement, development, compensation, integration and maintenance of people for the purpose of contributing to organizational, individual and societal goal."

- V. P. Michael- "Human resource management is to reflect a new philosophy, a new outlook, approach and strategy, which view an organization's manpower as its resources and assets and not as liabilities or mere hands".

- $\quad$ Bhatia S. K. - “process undertaken to promote the intellectual, moral, psychological, cultural, social and economic development of the individual so as to help him to achieve highest human potential as a resource for the community. It means a total all around development of the person so that he can contribute his best to the community and the nation."

- Leon C. Megginson - "From the national point of view, human resources may be defined the knowledge, skills, creative abilities, talents and aptitudes obtained in the population, whereas from the view point of the individual enterprise, they represent the total of the inherent abilities acquired knowledge and skills as exemplified in the talents and aptitudes of its employees".

\section{SMALL SCALE INDUSTRIES}

Small scale industries occupy a very important place in providing employment opportunities and contribute to a great extent to the industrial output and exports. The small scale sector has been receiving due attention and importance from the policy makers for its special character of low level of investment requirement, high potential of creating employment opportunities and high utilization of local resources. The definition of small scale industry has been varying from time to time and from country to country depending upon the pattern and stage of development, government policy and administrative set up of that particular country.

\section{FEW DEFINITIONS OF SMALL SCALE INDUSTRY}

For the first time the Fiscal Commission, Government of India, in 1950, defined small scale industry as one, which is operated mainly with hired labor consisting of 10 to 50 hands and with a fixed capital investment.

The Small Scale Industries Board in 1955 defined, "Small Scale industry as a unit employing less than 50 employees, if using power and less than 100 employees if not using power, and with a capital investment not exceeding Rs.5 lakhs".

In 1997 the capital investment limit for SSIs has been increased from Rs. 5 lakhs to Rs. 10 lakhs, in 1980 it has been raised to 20 lakhs and further to Rs.35 lakhs in 1985.

The New Industrial Policy 1991 raised the investment ceilings for plant and machinery to Rs. 60 lakhs for Small scale units. 
The SSIs has been currently defined in terms of the investment ceilings on the original value of the installed plant and machinery. In 1998, the Government of India fixed the ceiling as Rs.1 crorein plant and machinery for small scale industry.

In accordance with the provisions of Micro, Small \& Medium Enterprises Development (MSMED) Act, 2006, the Micro, Small and Medium Enterprises (MSME) are classified into two Groups

(a) Manufacturing Enterprises- enterprises engaged in the manufacture or production of goods pertaining to any industry specified in the first schedule to the industries (Development and regulation) Act, 1951). They are defined in terms of investment in plant and machinery.

(b) Service Enterprises- enterprises engaged in providing or rendering of services and are defined in terms of investment in equipment.

The limit for investment in plant and machinery/equipment for manufacturing/service enterprises, as notified vide S. O.1642(E) dtd 29-09-2006 are as under:

\begin{tabular}{|l|l|}
\hline \multicolumn{1}{|c|}{ Enterprises } & \multicolumn{1}{c|}{ Manufacturing Sector } \\
\hline Micro Enterprises & Investment in plant and machinery \\
\hline Small Enterprises & $\begin{array}{l}\text { More than twenty five lakh rupees but does not exceed five } \\
\text { crore rupees }\end{array}$ \\
\hline Medium Enterprises & More than five crore rupees but does not exceed ten crore rupees \\
\hline \multicolumn{2}{|c|}{ Service Sector } \\
\hline \multicolumn{1}{|c|}{ Enterprises } & \multicolumn{1}{c|}{ Investment in equipment } \\
\hline Micro Enterprises & Does not exceed ten lakh rupees \\
\hline Small Enterprises & More than ten lakh rupees but does not exceed two crore rupees \\
\hline Medium Enterprises & $\begin{array}{l}\text { More than two crore rupees but does not exceed five crore } \\
\text { rupees }\end{array}$ \\
\hline
\end{tabular}

\section{LITERATURE REVIEW}

Several studies had been carried, on the influence of HRM practices on the performance of small scale industries. Sundararaj and Meeraswaran (2017) observed that, HR departments in organizations are responsible for effective implementation of HR practices, which would improve the human resource management system. Ramila Ram Sing and Vadivelu (2016) opined that, Human resource is the prime contributor and performance appraisal techniques facilitate in increasing the output and motivational levels of the employees. Saira Hasan (2016) in her study indicated that, HRM practices have positive impact on employee performance. Seema Sangwan (2015) found that, there is a great impact of compensation on employee productivity, employee perception and satisfaction levels, which are crucial for the success of an organization. Rajni Khosla and P. K. Sharma (2014) in their study found that, the perception of employers and employees towards training needs to be changed, in order to improve the functioning of small and medium enterprises in the long run. Nina Gupta and Jason D. Shaw (2014) said that, compensation enhances the motivation and performance level of workforce and affects the employees' attitude and behavior as well. Gaafar Mohammed Abdalkrim (2012) examined that, human resource management practices like training and development, performance appraisal, compensation, job rotation and selecting system have positive correlation with organizational performance. Richard and Johnson (2001) examined that, strategic HRM has significant effect on return on equity and employee turnover of the organization. From the above studies it is clearly identified that there is a significant effect of HRM practices on the 
performance of the organization. The present study is carried in line with the above studies and tries to exhibit the effectiveness of HRM practices on the performance of small scale industries.

\section{OBJECTIVES OF THE STUDY}

- To understand the role of HR practices in small scale industries

- To examine the effectiveness of HR practices on the performance of small scale industries.

- $\quad$ To suggest measures for the improvement of HR practices in the organization.

The study primarily aims at identifying the impact of HR practices on the performance of SSIs. The key practices like recruitment, training and development, compensation and performance appraisal have been taken for the study. The influence of the above factors on the performance of the organization is measured on select SSI units.

\section{RESEARCH HYPOTHESES}

$\mathbf{H}_{\mathbf{0 1}}$ : There is no significant effect of recruitment on the sales growth of the organization.

$\mathbf{H}_{\mathbf{0 2}}$ : There is no significant effect of training and development on the sales growth of the organization.

$\mathbf{H}_{\mathbf{0 3}}$ : There is no significant effect of compensation on the sales growth of the organization.

$\mathbf{H}_{\mathbf{0 4}}$ : There is no significant effect of performance appraisal on the sales growth of the organization.

\section{RESEARCH METHODOLOGY}

The following diagram represents the conceptual framework to study the effectiveness of HRM practices on the organizational performance.

\section{CONCEPTUAL FRAMEWORK}

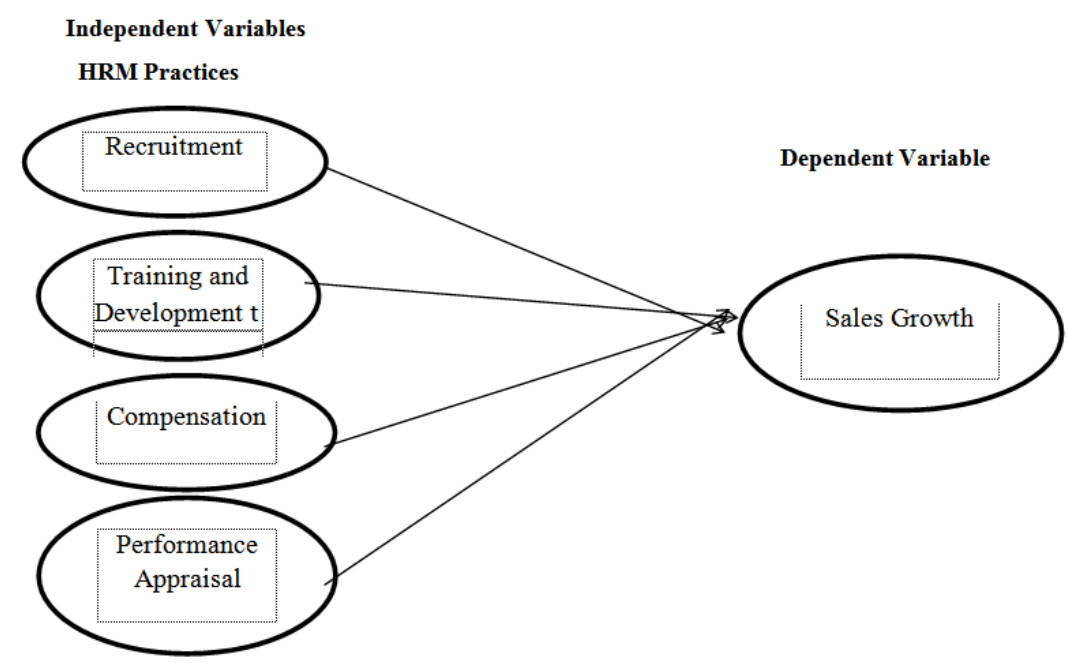

\section{RESEARCH DESIGN}

The study is done taking four human resource management practices which are considered to be crucial for the performance of the organization. 


\section{RESEARCH METHODS}

The researcher has taken both the primary and secondary data for the study. The primary data is collected by administering a structure questionnaire to different categories of employees of the organization. The secondary data is taken from the text books, company manuals, annual reports, journals and magazines.

\section{RESEARCH TOOL}

The questionnaire has been given to all the employees of the organizations taken for the study. The researcher has used Chi-square to test the effect of Human resource management practices on the sales growth of the organization.

\section{ANALYSIS AND DISCUSSION}

The researcher has used Chi-square test to know the effect of recruitment, training and development, compensation and performance appraisal on the sales growth of the organization. The results of the study are exhibited below.

Table 1: Recruitment* Sales Growth

\begin{tabular}{|l|c|c|c|}
\hline & Value & df & $\begin{array}{c}\text { Asymp. } \\
\text { Sig(2- } \\
\text { sided) }\end{array}$ \\
\hline $\begin{array}{l}\text { Pearson Chi- } \\
\text { square }\end{array}$ & $144.438^{\text {a }}$ & 26 & .000 \\
\hline $\begin{array}{l}\text { Likelihood } \\
\text { Ratio }\end{array}$ & 158.496 & 26 & .000 \\
\hline $\begin{array}{l}\text { Linear-by- } \\
\text { Linear } \\
\text { association }\end{array}$ & 8.016 & 1 & .005 \\
\hline $\begin{array}{l}\text { N of Valid } \\
\text { Cases }\end{array}$ & 550 & & \\
\hline
\end{tabular}

a. 15 cells $(35.7 \%)$ have expected count less than 5 . The minimum expected count is .31 .

Source: Calculated from the primary data

The above table reveals that the calculated chi-square value is 144.438 is greater than the table value at 26degrees of freedom taken at $\mathrm{p}=0.05$. Hence we reject the null hypothesis. Thus it shows that there is significant effect of recruitment on the sales growth of the organization.

Table 2: Training and Development* Sales Growth

\begin{tabular}{|l|c|c|c|}
\hline & Value & df & Asymp. Sig(2-sided) \\
\hline Pearson Chi-square & $202.978^{\mathrm{a}}$ & 26 & 0 \\
\hline Likelihood Ratio & 193.915 & 26 & 0 \\
\hline Linear-by-Linear association & 29.081 & 1 & 0 \\
\hline N of Valid Cases & 550 & & \\
\hline
\end{tabular}

a. 18 cells $(42.9 \%)$ have expected count less than 5 . The minimum expected count is .36

Source: Calculated from the primary data 
The above table reveals that the calculated chi-square value is 202.978 is greater than the table value at26 degrees of freedom taken at $\mathrm{p}=0.05$. Hence we reject the null hypothesis. Thus it shows that there is significant effect of training and development on the sales growth of the organization.

Table 3: Compensation* Sales Growth

\begin{tabular}{|l|l|l|l|}
\hline & Value & df & Asymp. Sig(2-sided) \\
\hline Pearson Chi-square & $250.027^{\mathrm{a}}$ & 24 & 000 \\
\hline Likelihood Ratio & 185.494 & 24 & 000 \\
\hline Linear-by-Linear association & 14.748 & 1 & 000 \\
\hline N of Valid Cases & 550 & & \\
\hline
\end{tabular}

a. 21 cells $(53.8 \%)$ have expected count less than 5. The minimum expected count is .36 .

Source: Calculated from the primary data

The above table reveals that the calculated chi-square value is 250.027 is greater than the table value at 24 degrees of freedom taken at $p=0.05$. Hence we reject the null hypothesis. Thus it shows that there is significant effect of compensation on the sales growth of the organization.

Table 4: Performance Appraisal* Sales Growth

\begin{tabular}{|l|c|c|c|}
\hline & Value & df & $\begin{array}{c}\text { Asymp. Sig(2- } \\
\text { sided) }\end{array}$ \\
\hline Pearson Chi-square & $225.179^{\mathrm{a}}$ & 20 & 0 \\
\hline Likelihood Ratio & 146.023 & 20 & 0 \\
\hline Linear-by-Linear association & 2.616 & 1 & 0.106 \\
\hline N of Valid Cases & 550 & & \\
\hline
\end{tabular}

a. 15 cells $(45.5 \%)$ have expected count less than 5 . The minimum expected count is .36 .

Source: Calculated from the primary data

The above table reveals that the calculated chi-square value is 225.179 is greater than the table value at 20 degrees of freedom taken at $p=0.05$. Hence we reject the null hypothesis. Thus it shows that there is significant effect of performance appraisal on the sales growth of the organization.

\section{FINDINGS OF THE STUDY}

The study has taken four HR practices to observe their effect on the organizational performance of small scale industries with respect to the sales growth.

- $\quad$ Recruitment has a positive and significant effect on the sales growth of small scale industries.

- Training and development has a positive and significant effect on the sales growth of small scale industries.

- Compensation has a positive and significant effect on the sales growth of small scale industries.

- $\quad$ Performance Appraisal has a positive and significant effect on the sales growth of small scale industries.

The results of the study has shown significant there is a positive and significant effect of HR practices on the sales growth of the small scale industries which inturn contribute to the overall development of the organization. 


\section{CONCLUSIONS}

The above study reveals that there is a positive and significant effect of Human Resource Management Practices on the sales growth of the organization and especially for the small scale industries. Thus small scale industries are suggested for the implementation of HR practices which will help them in achieving not only their organizational goals and objectives but also facilitate to improve the overall performance of the organization.

\section{REFERENCES}

1. Moorthy. M.V.'Human Resource Management'-R and M Associates Consultants, Bangalore.p-6

2. Basava K. D-Human Resource Development-VidhyvahiniPrakashana, Hubli (2000) p-1.2 3.

3. Michael V.P- Human Resource Management \& Human Relation, Himalaya Publishing House, Mumbai. p-723

4. Varma\&Aggarwal-Personnel Management and Industrial Relation-Ashish Publishing House, New Delhi. p-2 10.

5. Khan M.F- Human Resource Management in Hospitals-Paras Publishing, Hyderabad.(2007) p-5.

6. Gaafar Mohamed Abdalkrim, "The Impact of Human Resource management Practices on Organizational Performance in Saudi Banking Sector”, European Journal of Business and Management, Vol 4, No.21, 2012, pp.188-190.

7. Roopali Bajaj \& Shalini Sinha, Successful Human Resource Management Determinants to Build Good Employee Relations: A Quantitative Approach, International Journal of Human Resource Management and Research (IJHRMR), Volume 3, Issue 2, May - Jun 2013, pp. 31-36

8. Nina Gupta, et, al, "Employee Compensation: The neglected area of HRM research", Human Resource Management Review 24, 2014, pp.1-4.

9. RajniKhosla 'et,al' "Training and Development Practices in Small and Medium Enterprises: Exploring a Conceptual Framework", Pacific Business Review International, Vol.6, Issue 12, 2014, pp 105-112.

10. RamilaRam Sing, Dr. S.Vadivelu, (2016), "Performance Appraisal in India- A Review", International Journal of Applied Engineering Research, Vol. 11, No. 5, pp. 3229-3234.

11. SairaHasan, "Impact of HRM practices on Employee's performance", International Jour al of Academic Research in Accounting, Finance and Management Studies, Vol. 6, No 1, Jan 2016, pp.15-22 
